\title{
The value of a public value perspective on good governance in sport
}

\author{
Frank van Eekeren
}

\section{Introduction}

In today's world, it is not easy to express when an organisation qualifies well governed. It is no longer enough to frame 'good' only in terms of financial performance, effectiveness and efficiency. A private organisation such as Shell cannot suffice with creating financial value for its shareholders. The oil company realises that they are judged by how they act and how they live up to public values of honesty and integrity lest their reputation suffers near irreparable damage (Shell International Limited 2014). Public organisations, such as hospitals and municipalities, not only focus on result-oriented values such as effectiveness, and efficiency, but are also publicly assessed primarily on their contribution to the public sphere, such as a healthier and safer society (De Graaf, Huberts \& Smulders 2013). It can be argued that organisations, be they public or private, are expected by their stakeholders to contribute to the good of society (Benington 2011).

This contribution to the good of society can be described as 'creating public value' (Moore 1995). In a world in which, in addition to price and quality, distinguishing oneself from competitors is becoming increasingly important, it is more and more common to argue that organisations must have a purpose of 'public value' (Hollensbe et al. 2014; Van der Wal, De Graaf \& Lasthuizen 2008). Some authors even argue that the lack of public value creation by an organisation will lead to the marginalisation of said organisation (Bilolo 2018; Talbot 2011). As a result, the concept of public value is receiving increasing attention in the debate on good governance, both in the public and private sectors (Perry et al. 2014; Van der Wal, Nabatchi \& De Graaf 2015; Williams \& Shearer 2011).

Sport organisations cannot outrun this development. They can no longer do with developing sport, promoting elite sport performances and creating business value for their sponsors and financiers. It can be argued that traditional sport organisations have historically added to the public sphere by addressing social issues, but currently, sport organisations seem to have an increased motivation to act socially responsible and pay attention to doing good (Van Eekeren 2013). The great number of social projects run by professional sport clubs, often framed as corporate social responsibility (CSR) (Breitbarth et al. 2015), is an example of 
this, but the growing attention to good governance can be regarded as a way to create public value too. The motivation to create public value-although CSR or good governance actions are rarely described as such—comes partly from within, but is also encouraged from outside sport organisations.

An important driver behind the attention for public value creation is the professionalisation and commercialisation of sport in recent decades. It has inherently challenged the 'traditional' nature of sport organisations by embracing business-oriented management concepts (Beech \& Chadwick 2013), such as CSR and good governance. Another important driver is the recognition of sport having social meaning as well as its potential to positively contribute to social issues. Sport is increasingly recognised by politicians, policy makers, sponsors, media and the general public as a means or catalyst to promote public values, such as health, inclusion and sustainability (Coalter 2010; Van Eekeren 2016). In the dominant discourse of policy makers, sport is not so much valued for its own sake, but rather for its potential to cure or prevent social ills (Vermeulen 2011), and sport organisations are expected, and sometimes forced, to contribute actively to this. Finally, scandals in sport, such as sexual harassment, doping and match fixing, and the negative publicity that came with these scandals, are a driver for the aim to create public value, or, at the very least, to counter negative public value (NOC*NSF 2019). In short: sport organisations are explicitly held accountable for their social involvement and social responsibility and they are trying to add value to the public sphere in addition to the value for their athletes and their sponsors and financiers (Van Eekeren 2016; Waardenburg, Van den Hombergh \& Van Bottenburg 2019).

Sport organisations are also increasingly being held to account for public values that can be directly linked to good governance, such as lawfulness, integrity, equality, transparency, participation, legitimacy and accountability (Chappelet \& Mrkonjic 2013). This stems from the coming of age of the sport sector, the increasing public significance and public funding it holds and receives. Sport, just like the energy sector or the health care sector, is thus subject to (formal and informal) requirements for good governance, and sport organisations are making frantic efforts to draw up codes of good sport governance ${ }^{1}$ and to develop measuring instruments with the help of academics. The latter include definitions, descriptions and guidelines to create and measure the aforementioned public values ${ }^{2}$.

All this means that sport organisations, although traditionally organised privately-from associations to public limited companies—can be characterised as hybrid organisations with characteristics of both private and public organisations (Henne 2015; Lucassen \& Van der Roest 2011). They deal with both the public value issues of a private organisation such as Shell ('how do we act honestly and with integrity?') and those of public hospitals or municipalities ('how do we contribute to social issues, such as health, social cohesion and safety?'). The questions that can be raised from this are: To what extent can good governance in sport enable or support public value creation? Can theoretical findings from a public 
value perspective provide new or different insights regarding good governance in sport?

This chapter will reflect on the advantage of a public value perspective as one that does justice to the normative aspects of 'good' governance and as an alternative for prevailing approaches that are dominant in current practice and research. First, the chapter explains the origins of public value theory and introduces two of its approaches. It subsequently explains why the public value perspective can be relevant for sport organisations and how public value theory can actually affect implementation of good governance in sport. Afterwards, the limits and opportunities that derive from the public value perspective for good governance in sport will be discussed. The chapter concludes with the main insights and specific implications for researchers and practitioners.

\section{Public value theory}

Public values can be considered as one of the oldest issues in political thought as well as administrative practice (Beck Jørgensen \& Rutgers 2015). Nevertheless, now, in the early 21st century, there is an increased, renewed interest in the study of public values, especially in public administration (Lindgreen et al. 2019). According to Bryson, Crosby and Bloomberg (2014), it is a response to the challenges of a networked, multisector, no-one-wholly-in-charge world and the shortcomings of previous public administration approaches. The contemporary interest in public values counters an instrumental, managerial focus on public administration (Andersen \& Beck Jørgensen 2011) and a dominating neoclassical political economy (Bozeman 2007). While efficiency has been the main concern of traditional public administration (Noordegraaf 2015), values beyond efficiency and effectiveness are being pursued, debated, challenged and evaluated in the newly emerging public values approach.

It was Harvard professor Mark Moore who generated renewed attention to public values in the mid-1990s. Since then, the publication of many studies has seen public administrators elaborate, define and discuss the concept. Moore's ideas have been further developed and debated by various scholars in public value theory who draw on theoretical and epistemological foundations that differ from traditional public administration (e.g. Alford 2008; Benington 2009; Boyte 2011; Bozeman 2007; Denhardt \& Denhardt 2011; O'Flynn 2007; Stoker 2006).

\section{Defining public value}

Moore (1995) introduces public value as the contribution that organisations make to society and that is perceived by a wide audience. Talbot (2011) simply describes public value as 'what the public values', but to be a little more precise: public value provides an alternative and improved construct to explain the contribution of an organisation to the welfare of the society through contribution to the public sphere-the space where public values are explored and contested, and public 
value are created (Bryson et al. 2017; Habermas 1964). Public values are generally considered contributions that go beyond those of mere market economic considerations. They are made by organisations to society and/or the public sphere in relation to complex social issues. Examples are health, sustainability and integrity (Benington 2011; Leisink et al. 2013; Moore 1995).

At the same time, it is generally difficult to determine what public value is, what has public value, how it can be created and with whom (Meynhardt 2009). There appears to be no unequivocal opinion about what public value exactly is or which action is deemed to have public value. Public value depends on the predominant view in society of what is valuable (Talbot 2011). Benington (2015) has argued that public value is connected with the contests, debates and dialogues in a democratic society. In this sense, public value is a "contested democratic practice" (Benington 2015, p. 29) or, as Rhodes and Wanna (2007, p. 172) argue: "public value is highly contested territory, in which competing and conflicting interests can only be negotiated". Public values are therefore a constant subject of debate and there are different views on it.

\section{Public value and good governance: Two approaches}

In addition to the question of what public value is, a lot of research focuses on the question of how public value can be created. A resulting question concerns the relationship between good governance and public value or its creation. Two approaches can be distinguished in this context: good governance as a means to create public value and good governance as a public value in itself.

In the first approach, good governance can be regarded as the independent variable and public value as the dependent variable. Perry et al. (2014) for instance regard good governance as that which contributes to the good of society. Importantly, public value is not static or inherent here. Instead, it is achieved through the organisation's governance, which is presented in terms of normative aspirations for a 'good society'. In this approach, public value is a desirable outcome of good governance and there is good governance when sport organisations implement governance structures that are instrumental to the creation of certain public values. In relation to sport, frequently mentioned public values are health, social cohesion and social safety (Coalter 2010; Van Eekeren 2016; Waardenburg 2016), as is environmental sustainability to an increasing extent (McCullough $\&$ Kellison 2018). This approach implies that good governance principles in sport-f.e. transparency, democracy and accountability-should be viewed as means towards desirable ends-f.e. social cohesion, health and environmental sustainability - rather than administrative ends in themselves.

In the second approach, good governance can be seen as a public value in itself and some of its principles can be regarded as public values. This approach implies that the implementation of certain elements of good governance thus becomes a goal in itself. Various attempts have been made by scholars to define good governance principles as public values. Huberts and Van Hout (2011, p. 57) even 
speak of a "cacophony of values". Yet within this cacophony, three value clusters can be distinguished. Cluster 1 focuses on fair governance. This concerns values such as lawfulness, integrity and equality. Cluster 2 focuses on responsive governance. It concerns values such as transparency, participation, legitimacy and accountability. Cluster 3 concerns result-oriented management with values such as effectiveness, efficiency and professionalism (De Graaf, Huberts \& Smulders 2013). While many of these public values definitions were originally developed in other sectors, quite a number of them are reflected in attempts to define universal good governance principles for sport (e.g. Alm 2013; Chappelet \& Mrkonjic 2013; Geeraert 2016).

\section{Good governance in sport from a public value perspective}

When we take a look at good governance in sport from a public value perspective, there is one question that has to be answered first. Is good governance a means to an end or is it an end in itself? Do we consider it a tool that contributes to the good of society and, if so, do we assess this tool in terms of the degree to which it creates public value as perceived by a wide audience? Or is it rather good governance itself that we see as a public value? Do we see associated values-f.e. transparency, democracy and accountability-as public values in themselves? And is the question that we therefore have to ask above all else how we create such values? What are the criteria they would have to fulfil?

\section{Good governance as a means to create public value}

When good governance is seen as a means to create public values, such as health, social cohesion and safety, two things are important: (1) making the pursued values explicit and (2) making the relationship between the pursued values and good governance explicit.

First, sport organisations and their stakeholders should be explicit about what the public values they pursue are, how they can be defined and how they can be demonstrated. At the same time, they must realise, in accordance with public value theory, that they do not determine these values themselves. Instead, public values are defined and demonstrated in a continuous process with the relevant stakeholders. After all, public values cannot be objectively defined and established, and moreover, they are not static. Many sport organisations use good governance to focus on public values such as sportsmanship and respect, safety and the prevention of corruption, match fixing, doping and sexual harassment (e.g. IOC 2008; NOC*NSF 2019; UK Sport and Sport England 2017). Public value theory teaches that what can be meant by public values is determined by the sport organisations with their stakeholders in their specific context. The ultimate 'game' of defining and demonstrating public values takes place in an arena of stakeholders, each of whom occupies different positions and puts forward their 
interests in the arena (Van Eekeren 2016). The process of public value creation can be characterised as a struggle that cannot be separated from the sources of power available to stakeholders.

Second, based on public value theory, it should be clear what the explicit relationship is between good governance as a means and public value as an end. In many cases, good governance in sport is presented as a means of legitimising, safeguarding or restoring trust in sport, and good governance must try to prevent abuses in sport. All of this sounds like an approximation of good governance as an independent variable and public value as a dependent variable. However, practice has shown that the focus is mainly on the implementation of good governance principles (as an end) where the relationship with the ultimate goal (public value) is not clear. For example, in the discussion about the new code of good sport governance in the Netherlands, public value creation is mentioned as the highest goal, but at the same time, its relationship with the principles of good governance (transparency, democracy and accountability) is not explicit (NOC*NSF 2019).

\section{Good governance as a public value}

Most implementation aimed at good governance in sport focuses on good governance principles that are seen as public values and are therefore goals in themselves. The underlying idea is often to maintain or increase the quality of and the confidence in sport through the administrative structure and functioning of sport organisations. The good governance principles are usually enshrined and elaborated in codes, such as those of UK Sport and Sport Vlaanderen, and in measuring instruments, such as the Sport Governance Observer. From the perspective of public value theory, there are two important points of interest in this approach: (1) contextuality and (2) the use of multiple value clusters.

First, public value theory makes it clear that defining and establishing public values in terms of good governance principles is not universal, while good governance codes usually end with a list of abstract public values no one could oppose (De Graaf \& Paanakker 2014). It appears that abstract principles, such as democracy and transparency, can be put to good use in many parts of the world and in many sectors, but the meaning and effect may differ per sector, country, region and sport. The various codes and measuring instruments mentioned above have made the good governance principles contextual for sport. This means that these codes and measuring instruments, in addition to general principles such as transparency and democracy, pay attention to social responsibility (Alm 2013) and the autonomy of sport (Chappelet \& Mrkonjic 2013). But both the codes and measuring instruments are quite static. Once established by researchers, experts and/ or stakeholders, they acquire an 'absolute' character-all the while public value theory makes clear that the meaning of values such as transparency, democracy and accountability as well as social responsibility and autonomy are contestable, contextual and subject to change. Public value theory emphasises the normative 
aspirations of 'good' governance, which means a continuous debate with all stakeholders is necessary to define and construct what the public values are.

Second, as argued before, public value theory in relation to good governance makes it clear that different value clusters can be distinguished: public values aimed at fair governance, responsive governance and result-oriented governance. The developed good governance principles in sport, such as in the Basic Universal Principles of Good Governance of the Olympic and Sports Movement (IOC 2008) and Principles of Good governance in Sport (EU Expert Group Good Governance 2013), mainly fall within the second cluster. They emphasise values such as transparency, democracy and accountability, appropriate for responsive governance. This raises the question of whether codes and measuring instruments in sport should not pay more attention to fair governance and its related values such as legality, integrity and equality, and to performance-oriented governance and its related values such as effectiveness, efficiency and professionalism.

\section{Opportunities and limits of a public value perspective}

A public value perspective offers various opportunities to critically reflect on the current practice of good governance in sport and to propose new quality criteria. At the same time, this perspective also has a number of limitations.

\section{Critical reflections on good governance in sport}

First of all, the public value perspective makes it clear that although there is a lot of talk about (public) values in sport in practice and in policy, there is hardly an explicit debate about what is meant by these public values or whether good governance is regarded as a means or as an end. This can lead to an unfocused debate about the implementation and effectiveness of good governance in sport. For example, sport organisations and researchers often refer to good governance as a means of creating public values. However, in the implementation stage, the approach to good governance as an end winds up being used in most cases. It also happens that both approaches are intertwined in practice. An example for this is the Sport Governance Observer. It presents three dimensions (democracy, transparency and accountability) that represent public values in themselves, and a fourth (social responsibility) that focuses on preconditions for the creation of public value around social themes such as inclusion and sustainability.

Second, using public value theory as a lens reveals that good governance in sport can be more context and process oriented-whether good governance is seen as a means or as an end. Public values can be regarded as multidimensional constructs and involved actors create the strength of these constructs through the trust they have in each other and in an honest approach (O'Flynn 2007). It is about collective sense-making by stakeholders and the use of existing knowledge and experiences outside the network so that a broader assessment is made of possible public values. This means that the implementation of good governance in 
sport must be seen as a continuous debate, in which organisations must be able to deal with diversity in views. In this way, sport organisations can do justice to the specific context of the (national, regional or local) sport. As a consequence, this means that sport organisations must create the right conditions for the process of both defining and determining public value(s).

Third, from a public value perspective, good governance by a sport organisation concerns the creation of different types of public values. These public values can potentially conflict with each other. A subsequent and recurrent issue in public value theory is that not all of these values-however desirable they are-can be achieved at the same time (De Graaf \& Paanakker 2014). Public value theory makes it clear that different value clusters can clash and that it is important to recognise the ambiguous and contested nature of good governance principles in the implementation of good governance. Moreover, many oft-mentioned 'global' good governance principles such as transparency, rule of law and government effectiveness (Kaufmann, Kraay \& Mastruzzi 2008) may be conflicting or contradictory in policy and management decisions. Sport organisations must find a way to deal with the possible tensions or contradictions between, for example, efficiency and transparency, or between effectiveness and equality.

Another consideration is that sport organisations must also create other types of values, such as sportive values and business values. These values can in turn conflict with public values (Van Eekeren 2016). A mixed public/private profile of the sport organisations can produce contradictory incentives. Public tasks, for instance, do not obey the logic of the market, and the specific organisational culture of a sport organisation can be in conflict with entrepreneurship (Van Montfort 2008). This means that, in addition to the approach of good governance as a means to create public value and good governance as a public value in itself, a third approach is applicable: good governance defined as managing tensions between values, public or otherwise (Perry et al. 2014).

In this third approach, good governance occurs when multiple values are successfully combined in an organisation. In other words: the existence of good governance is determined by way of dealing with the conflicting values from these different clusters. Good governance ensures that a debate about value creation takes place and leads to the production of (potentially) conflicting values (De Graaf \& Van der Wal 2010). How this process is carried out in the stakeholder arena can be laid down in a number of quality criteria that approach the universal principles of good governance. An example could be involving everyone in a democratic process, being transparent about the procedure and ensuring clear supervision of the process.

\section{Critical reflections on a public value perspective}

Criticism of public value theory often arises from the complexity and ambiguity of public value as a theory and framework. For example, there are many public values (e.g. Andersen et al. 2012; Bozeman 2007; Meynhardt 2009) and they are 
not a settled or stable matter. Also, it is unclear "what the public values are" and "what adds value to the public sphere" (Hartley et al. 2016, p. 40) often causing tension. From its complexity and ambiguity, a public values approach has a number of limitations with regard to the implementation of good governance in sports.

First, this complexity and ambiguity has resulted in public value theory not providing concrete handles for implementation of good governance in organisational practice. This means that every organisation must determine in its own context which public values they attach to good governance and how they intend to implement this. A blueprint approach is not possible from a public value theory standpoint; it concerns a contextual and continuous process. At the same time, public value theory does not provide concrete tools for structuring the process either, although there is increasing knowledge about public value management (Stoker 2006), public value co-creation (Bryson et al. 2017) and creating public value through smart partnerships (Van Eekeren 2016).

Second, the ambiguity and complexity of public value theory makes assessing the outcomes of good governance in terms of public value very difficult. Determining objective, universal public values is not possible. This means, among other things, that public values once created cannot be examined in an unambiguous way and that comparison between different organisations and situations is extremely complex. This issue persists even despite the development of tools like a Public Value Scorecard (Lindgreen et al. 2019; Meynhardt 2015).

\section{Conclusion}

Sport organisations are expected to create public value, for example by contributing to social issues such as health, social cohesion and environmental sustainability. At the same time, they are expected to be governed in an honest and decent manner, by paying attention to certain values such as transparency, democracy and accountability. Now that these types of public values are increasingly seen as important benefits in sport organisations, a public value perspective offers the opportunity to use public values as a starting point for good governance in sport, rather than a marginal consideration (Beck Jørgensen \& Rutgers 2015). From a scientific point of view, there are two elements at the basis of the concept of public value: (1) being valuable and (2) enjoying trust from the perspective of the general public (Lindgreen et al. 2019; Moore 1995). A public value perspective on good governance in sport ensures that the implementation of good governance is more focused on the social outcomes and thus contributes to the legitimacy and public trust in sport and its organisations.

Based on the analysis in this chapter, it is important to be explicit, both in practice and in research, how the relationship between good governance and public values is viewed. At least three approaches are possible: (1) good governance as a means to create public value, (2) good governance as public value and an end in itself, (3) good governance as a process of managing tensions between 
(public) values. Each approach gives practitioners and researchers a specific perspective on good governance in sport that can help sharpen the debate on both implementation and research.

At the same time, it can be concluded that public value theory doesn't provide concrete handles for policy makers and managers due to its ambiguity and complexity. A managerial approach based on a blueprint does not fit the public value perspective. This might warrant a rethinking of the instrumentality of many of the current approaches and good governance codes, and puts a focus on processes instead of procedures and regulations. Sport organisations consequently should not spend a great deal of time, energy and resources on meeting compliance obligations, but rather on embedding good governance values in the hearts and minds of their organisations and partnerships. Managing good governance from a public values perspective is to a large extent addressing the intrinsic motivation of the organisation aimed at the higher social goal.

By its very nature, public value theory doesn't provide robust methodologies to assess public value as an outcome of good governance. A public value perspective requires that scholars draw from different theoretical and epistemological foundations. The positivist idea of one coherent theory of everything does not go well with public value theory, but a social-constructivist approach does. This also means that approaches other than the currently prevailing methodological ones are required; approaches that allow empirical research to give insights into the processes of public value creation in the arena of stakeholders on one hand, and the performance of organisations in terms of good governance related to public values on the other.

Two ways for further research can be recommended. First, research could examine whether and how public value is constructed in and by sport organisations, whether and how it is argued for by different agents and groups, in what organisational, institutional and social contexts, and what type of perceived outcomes this yields. Research questions could focus on where and how value is added through organisational and partnership processes and how public value is often co-produced with citizens and other partners and stakeholders in sport. Second, while performance management scholars have examined activities and outputs from public organisations, there has been less research about the value created (or destroyed) in terms of legitimacy, trust, social justice and so on. To make public value measurable, Meynhardt (2015) developed a scorecard that measures the public value of each project, decision or transaction along five dimensions: social, moral, aesthetic and utilitarian. It may be interesting to investigate whether this scorecard can be made applicable for good governance in sport.

Finally, it is striking how, now that sport organisations, governments, and other stakeholders all over the world feel the need to promote good governance in sport, the concept of public value and public value theory remain underexposed in the debate. It can be argued that a public value perspective does justice to the normative aspects of 'good' governance. A public value perspective requires that policymakers, managers and researchers alike consider good governance in 
sport as a relative, evolving and culturally defined aspiration (Evans 2012). It also provides alternatives for the limitations of the prevailing instrumental and positivist approaches towards good governance in sport that are dominant in current practice and research.

\section{Notes}

1. e.g. A Code for Sports Governance by UK Sport and Sport England (2017) and the Code of Good Governance in Flemish Sport Federations by Sport Vlaanderen (2016).

2. e.g. The Sport Governance Observer (Geeraert 2015).

\section{References}

Andersen, LB \& Beck Jørgensen, T 2011, 'An Aftermath of New Public Management: Regained Relevance of Public Values and Public Service Motivation', in T Christensen \& P Lægreid (eds), The Ashgate Research Companion to New Public Management, Ashgate, Oxon, pp. 335-48.

Andersen, LB, Beck Jørgensen, T, Kjeldsen, AM, Pedersen, LH, \& Vrangbæk, K 2012, 'Public Values and Public Service Motivation: Conceptual and Empirical Relationships', The American Review of Public Administration, vol. 43 no. 3, pp. 292-311. doi: $10.1177 / 0275074012440031$

Alford, J 2008, 'The Limits to Traditional Public Administration, or Rescuing Public Value from Misrepresentation', Australian Journal of Public Administration, vol. 67, no. 3, pp. 357-66. doi:10.1111/j.1467-8500.2008.00593.x

Alm, J (eds) 2013, Action for Good Governance in International Sport Organisations, Play the Game/Danish Institute for Sports Studies, Aarhus.

Beck Jørgensen, T \& Rutgers, MR 2015, 'Public Values: Core or Confusion? Introduction to the Centrality and Puzzlement of Public Values Research', The American Review of Public Administration, vol. 45, no. 1, pp. 1-9. doi:10.1177/0275074014545781

Beech, J \& Chadwick, S 2013, 'Introduction: The Commercialisation of Sport', in J Beech \& S Chadwick (eds), The Business of Sport Management, Pearson Education Limited, Harlow, pp. 3-23.

Benington, J2009, 'Creating the Public in Order to Create Public Value?', InternationalJournal of Public Administration, vol. 32, no. 3-4, pp. 232-49. doi:10.1080/01900690902749578

Benington, J 2011, 'From Private Choice to Public Value?', in J Benington \& MH Moore (eds), Public Value: Theory and Practice, Palgrave Macmillan, New York, pp. 31-51. doi:10.1007/978-0-230-36431-8_2

Benington, J 2015, 'Public Value as a Contested Democratic Practice', in J Benington (eds), Creating Public Value in Practice, Routledge, London, pp. 29-48. doi:10.1201/ b18116-4

Bilolo, C 2018, Legitimacy, public value, $\mathcal{E}$ capital allocation, Doctoral dissertation, University of St. Gallen, St. Gallen.

Boyte, HC 2011, 'Constructive Politics as Public Work: Organizing the Literature', Political Theory, vol. 39, no. 5, pp. 630-60. doi:10.1177/0090591711413747

Bozeman, B 2007, Public Value and Public Interest: Counterbalancing Economic Individualism, Georgetown University Press, Washington, DC. 
Breitbarth, T, Walzel, S, Anagnostopoulos, C \& Van Eekeren, F 2015, 'Corporate Social Responsibility and Governance in Sport: 'Oh, the Things You Can Find, If You Don't Stay Behind!”', Corporate Governance: The International Journal of Business in Society, vol. 15, no. 2, pp. 254-73. doi:10.1108/CG-02-2015-0025

Bryson, JM, Crosby, BC \& Bloomberg, L 2014, 'Public Value Governance: Moving Beyond Traditional Public Administration and the New Public Management', Public Administration Review, vol. 74, no. 4, pp. 445-56. doi:10.1111/puar.12238

Bryson, JM, Sancino, A, Benington, J \& Sørensen, E 2017, 'Towards a Multi-Actor Theory of Public Value Co-Creation', Public Management Review, vol. 19, no. 5, pp. 640-54. doi: 10.1080/14719037.2016.1192164

Chappelet, JL \& Mrkonjic, M 2013, Basic Indicators for Better Governance in International Sport (BIBGIS): An Assessment Tool for International Sport Governing Bodies, IDHEAP, Lausanne.

Coalter, F 2010, 'The Politics of Sport-for-Development: Limited Focus Programmes and Broad Gauge Problems?', International Review for the Sociology of Sport, vol. 45, no. 3, pp. 295-314. doi:10.1177/1012690210366791

De Graaf, G, Huberts, L \& Smulders, R 2013, Publieke waarden van goed bestuur in de praktijk, Vrije Universiteit, Amsterdam.

De Graaf, G \& Paanakker, H 2014, 'Good Governance: Performance Values and Procedural Values in Conflict', The American Review of Public Administration, vol. 45, no. 6, pp. 635-52. doi:10.1177/0275074014529361

De Graaf, G \& Van der Wal, Z 2010, 'Managing Conflicting Public Values: Governing with Integrity and Effectiveness', The American Review of Public Administration, vol. 40, no. 6, pp. 623-30. doi:10.1177/0275074010375298

Denhardt, JV \& Denhardt, RB (eds) 2011. The New Public Service: Serving, Not Steering, M. E. Sharpe, Armonk, NY.

EU Expert Group Good Governance 2013, Deliverable 2: Principles of Good Governance in Sport, European Commission, Brussels.

Evans, M 2012, 'Beyond the Integrity Paradox - Towards 'Good Enough' Governance?', Policy Studies, vol. 33, no.1, pp. 97-113. doi:10.1080/01442872.2011.637324

Geeraert A 2015, Sports Governance Observer 2015. The Legitimacy Crisis in International Sports Governance, Play the Game/Danish Institute for Sports Studies, Copenhagen.

Geeraert, A 2016, 'Indicators and Benchmarking Tools for Sports Governance', in International Transparency (ed) Global Corruption Report: Sport, Routledge, Oxon, pp. 56-61.

Habermas, J 1964, 'The Public Sphere: An Encyclopedia Article', Original in German, reprinted in: J Gripsrud, H Moe, A Molander \& G Murdock (eds) 2010, The Idea of the Public Sphere: A Reader, Lexington Books, Lanham MD, pp. 114-120.

Hartley, J, Alford, J, Knies E \& Douglas, S 2016, Towards an Empirical Research Agenda for Public Value Theory', Public Management Review, vol. 19, no. 5, pp. 670-85. doi:10. 1080/14719037.2016.1192166

Henne, K 2015, 'Reforming Global Sport: Hybridity and the Challenges of Pursuing Transparency', Law E Policy, vol. 37, no. 4, pp. 324-49. doi:10.1111/lapo.12044

Hollensbe, E, Wookey, C, Hickey, L, George, G \& Nichols, V 2014, 'Organisations with Purpose: From the Editors', Academy of Management Journal, vol. 57, no. 5, pp. 1227-34. doi:10.5465/amj.2014.4005

Huberts, LWJC \& Van Hout, ET 2011, 'Goed bestuur: kiezen of delen?', Bestuurskunde, vol. 20, no. 2, pp. 53-62. 
IOC 2008, Basic Universal Principles of Good Governance of the Olympic and Sports Movement, IOC, Lausanne.

Kaufmann, D, Kraay, A \& Mastruzzi, M 2008, Governance Matters VII: Aggregate and Individual Governance Indicators 1996-2007, The World Bank, Washington, DC. doi:10.1596/1813-9450-4654

Leisink, P, Boselie, P, Van Bottenburg, M \& Hosking, DM 2013, Managing Social Issues. A Public Values Perspective, Edward Elgar Publishing, Cheltenham. doi:10.4337/9781781006962

Lindgreen, A, Koenig-Lewis, N, Kitchener, M, Brewer, JD, Moore, MH \& Meynhardt, T (eds) 2019, Public Value: Deepening, Enriching, and Broadening the Theory and Practice, Routledge, London. doi:10.4324/9781315163437

Lucassen, J \& Van der Roest, JW 2011, 'Management of Hybrid Organisations in the Voluntary Sports Sector', in 19th Conference of the European Association for Sport Management Congress, Madrid, WJH Mulier Instituut, Utrecht, pp. 7-10.

McCullough, BP \& Kellison, T 2018, Routledge Handbook of Sport and the Environment, Routledge, Oxon. doi:10.4324/9781315619514

Meynhardt, T 2009, 'Public Value Inside: What Is Public Value Creation?', International Journal of Public Administration, vol. 32, no. 3-4, pp. 192-219. doi:10.1080/01900690902732632

Meynhardt, T 2015, 'Public Value: Turning a Conceptual Framework into a Scorecard', in J Bryson, BC Crosby \& L Bloomberg (eds), Public Value and Public Administration. Georgetown University Press, Washington, DC, pp. 147-69.

Moore, MH 1995, Creating Public Value: Strategic Management in Government, Harvard University Press, Cambridge, MA.

NOC*NSF 2019, Visie en uitwerking code Goed Sportbestuur. Waarde voor de Sport (Vision and Elaboration of the Code Good Sport Governance. Value for Sport), NOC*NSF, Arnhem.

Noordegraaf, M 2015, Public Management: Performance, Professionalism and Politics, Macmillan International Higher Education, London. doi:10.1007/978-1-13749644-7_5

O'Flynn, J 2007, 'From New Public Management to Public Value: Paradigmatic Change and Managerial Implications', Australian Journal of Public Administration, vol. 66, no. 3, pp. 353-66. doi:10.1111/j.1467-8500.2007.00545.x

Perry, JL, De Graaf, G, Van der Wal, Z \& Van Montfort, C 2014, 'Returning to Our Roots: "Good Government" Evolves to "Good Governance", Public Administration Review, vol. 74, no. 1 pp. 27-8. doi:10.1111/puar.12164

Rhodes, RAW \& Wanna, J 2007, 'The Limits to Public Value, or Rescuing Responsible Government from the Platonic Guardians', Australian Journal of Public Administration, vol. 66, no. 4, pp. 406-21. doi:10.1111/j.1467-8500.2007.00553.x

Shell International Limited 2014, Shell General Business Principles, Shell, The Hague.

Sport Vlaanderen 2016, Code of Good Governance in Flemish Sport Federations, Sport Vlaanderen, Brussels.

Stoker, G 2006, 'Public Value Management: A New Narrative for Networked Governance', The American Review of Public Administration, vol. 36, no. 1, pp. 41-57. doi: $10.1177 / 0275074005282583$

Talbot, C 2011, 'Paradoxes and Prospects of 'Public Value", Public Money $\mathbb{E}$ Management, vol. 31, no. 1, pp. 27-34. doi:10.1080/09540962.2011.545544

UK Sport and Sport England 2017, A Code for Sports Governance. 
Van der Wal, Z, De Graaf, G \& Lasthuizen, K 2008, 'What's Valued Most? A Comparative Empirical Study on the Differences and Similarities Between the Organisational Values of the Public and Private Sector', Public Administration, vol. 86 no. 2, pp. 465-82. doi:10.1111/j.1467-9299.2008.00719.x

Van der Wal, Z, Nabatchi, T \& De Graaf, G 2015, 'From Galaxies to Universe: A Cross-Disciplinary Review and Analysis of Public Values Publications from 1969 to 2012', The American Review of Public Administration, vol. 45, no.1, pp. 13-28. doi: $10.1177 / 0275074013488822$

Van Eekeren, F 2013, 'Corporate Social Responsibility and Professional Football Clubs in the Netherlands: Juggling Value and Values in a Local Context', in P Leisink, P Boselie, M van Bottenburg \& DM Hosking (eds), Managing Social Issues. A Public Values Perspective, Edward Elgar Publishing, Cheltenham.

Van Eekeren, F 2016, De waarde(n)volle club. Het besturen en managen van publieke waardencreatie in voetbalorganisaties (Values and Clubs. Managing and Governing Public Value Creation in Football Organisations), Arko Sports Media, Nieuwegein.

Van Montfort, C 2008, Besturen van het onbekende. Goed bestuur bij publiek-private arrangementen (Governing the Unknown. Good Governance at Public-Private Arrangements), Lemma, The Hague.

Vermeulen, J 2011, 'The Bridge as Playground: Organizing Sport in Public Space', Culture and Organisation, vol. 17, no. 3, pp. 231-51. doi:10.1080/14759551.2011.569387

Waardenburg, M 2016, 'Which Wider Social Roles? An Analysis of Social Roles Ascribed to Voluntary Sports Clubs', European Journal for Sport and Society, vol. 13, no. 1, pp. 38-54. doi:10.1080/16138171.2016.1153883

Waardenburg, M, Van den Hombergh, S \& Van Bottenburg, M 2019, Bouwen aan maatschappelijke waarden: Publiek-private samenwerking bij multifunctionele sportaccommodatie (Building Social Values. Public-Private Collaboration at Multifunctional Sport Facilities), Boom Bestuurskunde, The Hague.

Williams, I \& Shearer, H 2011, 'Appraising Public Value: Past, Present and Futures', Public Administration, vol. 89, no. 4, pp. 1367-84. doi:10.1111/j.1467-9299.2011.01942.x 